\title{
Prognostic value of plasma von Willebrand factor levels in major adverse cardiovascular events: a systematic review and meta-analysis
}

Mengge Fan ${ }^{1,2}$, Xia Wang ${ }^{3}$, Xun Peng ${ }^{1,2}$, Shuo Feng ${ }^{1,2}$, Junyu Zhao ${ }^{4}$, Lin Liao ${ }^{4}$, Yong Zhang ${ }^{5}$, Yinglong Hou ${ }^{5}$ and Ju Liu' ${ }^{1 *}$ (D)

\begin{abstract}
Background: Prediction of major adverse cardiovascular events (MACEs) may offer great benefits for patients with coronary artery disease (CAD). Von Willebrand factor (VWF) is stored in endothelial cells and released into blood plasma upon vascular dysfunction. This meta-analysis was performed to evaluate the prognostic value of plasma vWF levels in CAD patients with MACEs.

Methods: A total of 15 studies were included in this meta-analysis through the search in PubMed, Embase and CNKI. Data were collected from 960 patients who had MACEs after CAD and 3224 controls nested without the adverse events. The standard mean difference (SMD) and 95\% confidence intervals (95\% Cl) were calculated using random-effects model.

Results: The plasma vWF levels examined at $24 \mathrm{~h}$ and $48 \mathrm{~h}$ after admission were significantly higher in CAD patients with MACEs than those without. The pooled SMD among the MACEs group and the non-MACEs group was $0.55(95 \% \mathrm{Cl}=0.30-0.80, P<0.0001)$ and $0.70(95 \% \mathrm{Cl}=0.27-1.13, P=0.001)$, respectively. However, no significant difference was found in plasma VWF levels on admission between the two groups.
\end{abstract}

Conclusion: Plasma VWF level in CAD patients examined at $24 \mathrm{~h}$ and $48 \mathrm{~h}$ after admission might be an independent prognostic factor for MACE.

Keywords: Major adverse cardiovascular events, Coronary artery disease, von Willebrand factor, Meta-analysis

\section{Background}

Coronary artery disease $(\mathrm{CAD})$ is characterized by the occlusion or stenosis of coronary artery mostly caused by atherosclerosis, and is one of the leading causes of mortality in humans $[1,2]$. Patients with CAD are vulnerable in development of major cardiovascular events (MACEs) including nonfatal acute myocardial infarction, unstable angina, stroke, transient ischemic attack, peripheral arterial occlusive disorder, and death [3]. According to previous long-term follow-up studies, the

\footnotetext{
* Correspondence: ju.liu@sdu.edu.cn

'Laboratory of Microvascular Medicine, Medical Research Center, Shandong Provincial Qianfoshan Hospital, The First Affiliated Hospital of Shandong First Medical University, 16766 Jingshi Road, Jinan 250014, Shandong, China Full list of author information is available at the end of the article
}

incidence of MACEs development after CAD ranges from 21 to 49\% [4], while the recurrence rates of MACEs are up to $75 \%$ within 3 years [5]. These events are typically caused by the formation of thrombus and insufficient blood supply. Identifying risk factors for the development of MACEs is of great value in the prognosis of CAD patients.

Von Willebrand factor (vWF) is a large multimeric glycoprotein required for the formation of hemostatic plugs and arterial thrombi [6]. vWF adheres platelets to the blood vessel wall, and acts as a plasma carrier for factor VIII to prevent its degradation in the blood circulation $[7,8]$. After synthesis, vWF is stored in the Weibel-Palade bodies of endothelial cells and the $\alpha$-granules of platelets $[9,10]$. The stored vWF is rapidly released at moments of 
endothelial cell damage, thus it is considered as a promised biomarker for endothelial dysfunction [11]. In addition, studies have shown that the plasma vWF derived from coronary vascular endothelial cells is significantly elevated when coronary artery injury occurs [12], indicating a pathogenesis role of vWF in the progression of CAD. Increased level of vWF has been recognized as an independent predictor of CAD in general population [9]. However, the prognostic role of vWF in CAD patients remains controversial. Several studies demonstrate a weak association between elevated vWF level and adverse outcomes in patients with CAD [13]. The current meta-analysis was performed to evaluate the prognostic value of plasma vWF in patients with CAD, in terms of MACEs.

\section{Methods}

\section{Search strategy}

We searched for all publications concerning the association between vWF and CAD up to July 2018. The literatures were searched in PubMed, Embase database and CNKI. The search strategy was composed by the following search terms (vWF OR Willebrand Protein OR von Willebrand Factor OR Factor VIIIR-Ag) AND (Coronary Disease OR coronary artery disease OR CAD OR CHD OR Myocardial Infarction OR AMI OR Acute coronary syndrome OR ACS OR angina) AND (major adverse cardiac events OR mortality OR death OR prognosis).

\section{Study selection}

Inclusion criteria were as follows: (1) cohort studies enrolling patients with CAD (myocardial Infarction, acute coronary syndrome and stable CAD); (2) data on plasma vWF was reported; (3) MACEs or mortality following CAD were recorded; (4) studies written in English or Chinese. Exclusion criteria are as follows: (1) patients without CAD; (2) there is no definitive value of plasma vWF.

\section{Data extraction}

Two independent reviewers extracted the following data from each eligible studies: first author's name, year of publication, mean age, sample size, gender, mean and standard deviation (mean \pm SD) or mean and standard error (mean $\pm \mathrm{SE}$ ) of plasma vWF concentration, definition of MACEs, mean or median follow-up duration, treatment modality, data regarding baseline and followup concentrations of vWF. Moreover, if the articles provide the data of median and interquartile range (IQR) format or mean and $p$ value, we calculated the SMD according to the formulations recommended by Cochrane Handbooks. Any discrepancy in data extraction was resolved through discussion with a third reviewer.

\section{Quality assessment}

Two independent authors assessed the methodological quality according to the Newcastle-Ottawa Quality Assessment scale (NOS) for cohort study. Total NOS score ranged from 0 to 9 stars. Those scored $\geq 7$ stars were considered as high quality and those scored $\leq 5$ as low quality.

\section{Statistical analysis}

Meta-analyses were conducted on Review Manager software (RevMan5.3, Cochrane Collaboration, Oxford, UK, http://community.cochrane.org) and STATA software (Stata Corp, College Station, Texas, USA). The SMD and $95 \%$ confidence intervals were calculated using a generic inverse variance approach. The overall effects were determined by $\mathrm{Z}$-test and $P$-value $<0.05$ were considered as statistically significant.

The heterogeneity across studies was tested by CochranQ statistics and $\mathrm{I}^{2}$ statistics. A random-effects model was used due to significant heterogeneity. Subgroup analyses were conducted to identify the source of potential heterogeneity based on the duration of followup, PCI, and severity of CAD. Meta-regression was also conducted to explore the potential heterogeneity. $P<$ 0.05 was considered statistically significant. Sensitivity analysis was performed by removing studies one by one to estimate the stability of meta-analysis.

\section{Results}

Search results and characteristics of included studies

A total of 1382 publications were identified by the search strategy, and 1324 publications remained in this study after removal of duplicates. After carefully reviewing the titles and abstracts, 44 candidate articles were screened out for further full-text reading, and 1280 unrelated articles were excluded. In addition, 27 full-text reviewed articles were excluded due to disqualification of inclusion criteria, 15 studies were included in this meta-analysis. Search progress was shown in Fig. 1. Of these 15 studies, 4 studies were conducted in China, 3 in Austria, 3 in UK, 2 in Germany, 1 in USA, 1 in Norway and 1 in France. A total of 4184 patients with CAD were identified and analyzed. Individual study sample sizes varied from 58 to 1045, and the duration of follow-up ranged from 30 days to 13 years. The included studies provided the plasma level of vWF at different time points after CAD (on admission, $24 \mathrm{~h}, 48 \mathrm{~h}$ ). The main characteristics of the studies were shown in Table 1.

\section{Plasma vWF and MACEs}

The meta-analyses were conducted according to the time points of vWF examination (on admission, $24 \mathrm{~h}$ and $48 \mathrm{~h}$ after admission). Consistent with previous reports, we found that the plasma level of vWF is elevated in CAD patients. The result of meta-analyses further to reveal that 


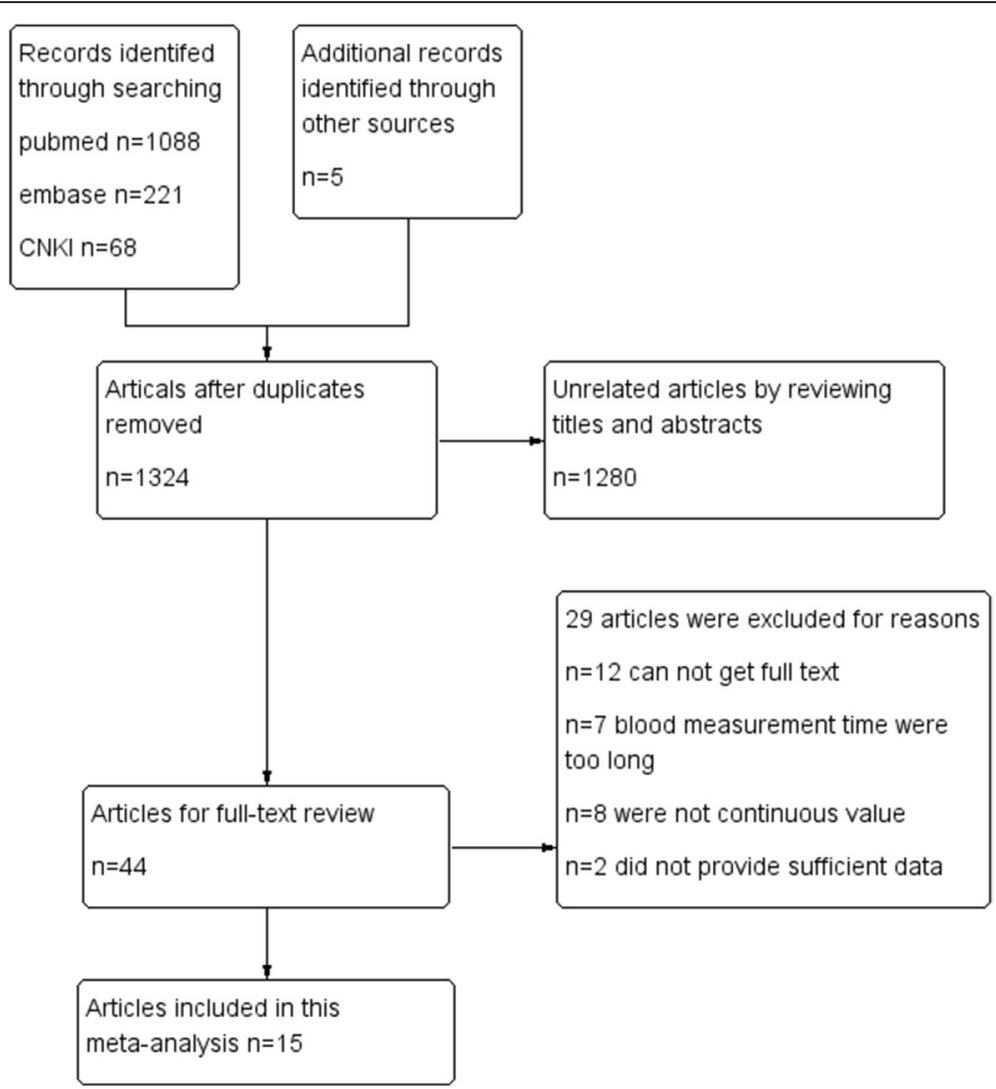

Fig. 1 The flow chart of the literature search and selection process

plasma level of vWF is significantly higher in CAD patients with MACEs than those without MACEs (Fig. 2). The pooled SMD for vWF examined at $24 \mathrm{~h}$ and $48 \mathrm{~h}$ after admission was $0.55(95 \% \mathrm{CI}=0.30-0.80, P<0.0001)$ and 0.70 (95\% CI $=0.27-1.13, P=0.001$ ), respectively. However, there was no significant difference in plasma level of vWF examined on admission between the two groups. The pooled SMD was $-0.25(95 \% \mathrm{CI}=-0.75-0.06, P=0.12)$. In addition, heterogeneity across studies was present.

\section{Quality evaluation}

Four studies $[3,4,14,15]$ with 8 NOS scores and eight studies [10, 16-22] with 7 NOS scores were considered as good quality. Other studies [13, 23, 24] achieved 6 scores indicating moderate quality. The results of the quality assessment of the included studies were shown in Table 2.

\section{Heterogeneity}

Subgroup analyses were conducted to evaluate potential sources of heterogeneity. Include studies were subgrouped according to the duration of follow-up. As shown in Table 3, the pooled effects of the metaanalyses were not reversed by the duration of follow-up. However, when subgrouped by the severity of CAD, a significant difference in SMD in vWF plasma levels examined at $24 \mathrm{~h}$ after admission was found between the subgroups. The pooled SMD was 0.67 (95\% CI $=0.47-$ $0.86, P<0.00001)$ for acute coronary syndrome (ACS) and myocardial infarction (MI) patients and was 0.21 (95\% CI $=-0.03-0.45, P=0.09$ ) for stable CAD patients. No significant difference in SMD in vWF plasma levels examined at $24 \mathrm{~h}$ after admission was found between patients treated with PCI (SMD $=0.63,95 \% \mathrm{CI}=0.42-0.84$, $P<0.00001)$ and those without PCI (SMD $=0.33,95 \%$ $\mathrm{CI}=0.11-0.54, P=0.003)$. To validate the results from subgroup analyses, we performed meta-regression to determine the source of heterogeneity. The associations between types of coronary disease, high range of follow up sample size, patients treated with PCI and the utilization of antiplatelet or anticoagulation were evaluated. As shown in Table 4, types of coronary disease, high range of follow up sample size, patients treated with PCI, and the utilization of antiplatelet or anticoagulation were not the source of heterogeneity in vWF plasma levels examined on admission (types of coronary disease: $P=0.489$; high range of follow up sample size: $P=0.364$; patients treated with PCI: $P=0.725$; the utilization of antiplatelet: $P=0.527$; the utilization of anticoagulation drugs: $P=0.509$ ). However, both high range of follow up sample size and the utilization of antiplatelet or 
Table 1 Characteristics of the studies included in the meta-analysis

\begin{tabular}{|c|c|c|c|c|c|c|c|c|c|c|}
\hline Year & Author & $\begin{array}{l}\text { Blood } \\
\text { Sampling } \\
\text { Schedule }\end{array}$ & Patients & $\begin{array}{l}\text { Age, } \\
\text { y C/ } \\
\text { CTL }\end{array}$ & $\begin{array}{l}\text { Sample } \\
\text { size C/ } \\
\text { CTL }\end{array}$ & $\begin{array}{l}\text { Treatment } \\
\text { modality }\end{array}$ & Definition of MACEs & $\begin{array}{l}\text { Measuring } \\
\text { Methods }\end{array}$ & $\begin{array}{l}\text { Rates } \\
\text { of HF } \\
\text { C/CTL }\end{array}$ & $\begin{array}{l}\text { Follow } \\
\text { up }\end{array}$ \\
\hline 2016 & HAMID & $24 \mathrm{~h}$ & STEMI & $\begin{array}{l}57 / \\
53\end{array}$ & $17 / 61$ & $\begin{array}{l}\mathrm{PCl}, \\
\text { Thrombolytic }\end{array}$ & $\begin{array}{l}\text { All-cause mortality, recurrent nonfatal } \\
\text { Ml, or HF and the secondary endpoint } \\
\text { of early adverse LV remodeling }\end{array}$ & ELISA & NR & 30 days \\
\hline 2015 & Liu & Admission & STEMI & $\begin{array}{l}58 / \\
60\end{array}$ & $30 / 102$ & $\mathrm{PCl}$ & $\begin{array}{l}\text { Recurrent MI, heart failure readmission, } \\
\text { unplanned repeat revascularization, } \\
\text { malignant dysrhythmia, stroke, or } \\
\text { pulmonary embolism }\end{array}$ & ELISA & NR & 1 year \\
\hline 2013 & Leu & Admission & $C A D$ & $\begin{array}{l}68 / \\
67\end{array}$ & $33 / 42$ & Antiplatelet & $\begin{array}{l}\text { CV death, nonfatal AMI, unstable } \\
\text { angina, stroke, transient ischemic } \\
\text { attack, or peripheral arterial occlusive } \\
\text { disorder }\end{array}$ & ELISA & NR & $\begin{array}{l}40 \\
\text { months }\end{array}$ \\
\hline 2013 & Hyseni & Admission & ACS & $\begin{array}{l}67.5 / \\
76.8\end{array}$ & $293 / 46$ & $\begin{array}{l}\mathrm{PCl}, \\
\text { Antithrombotic }\end{array}$ & All-cause mortality & ELISA & NR & 4 years \\
\hline 2008 & Yu & $\begin{array}{l}\text { Admission, } \\
12 \mathrm{~h}, 48 \mathrm{~h}\end{array}$ & ACS & $\begin{array}{l}68 / \\
64\end{array}$ & $22 / 48$ & Anticoagulation & $\begin{array}{l}\text { Death, } \mathrm{Ml} \text { or recurrent } \mathrm{Ml} \text {, and } \\
\text { recurrent angina }\end{array}$ & ELISA & NR & 30 days \\
\hline 2008 & BOOS & $24 \mathrm{~h}$ & ACS & $\begin{array}{l}69 / \\
60.6\end{array}$ & $42 / 169$ & $\begin{array}{l}\text { Thrombolysis, } \\
\text { PCl }\end{array}$ & $\begin{array}{l}\text { CV death, non-fatal Ml, readmission } \\
\text { with acute } \mathrm{HF} \text { and stroke, and } \mathrm{CV} \\
\text { death separately. }\end{array}$ & ELISA & $\begin{array}{l}28.6 / \\
7.6\end{array}$ & $\begin{array}{l}338 \\
\text { days }\end{array}$ \\
\hline 2006 & Fuchs & $24 \mathrm{~h}$ & ACS & $\begin{array}{l}60 / \\
57\end{array}$ & $58 / 150$ & $\begin{array}{l}\mathrm{PCl}, \\
\text { Thrombolysis }\end{array}$ & $\begin{array}{l}\text { Recurrent non-fatal MI (STEMI and } \\
\text { NSTE-MI) }\end{array}$ & Turbidometry & NR & $\begin{array}{l}28 \\
\text { months }\end{array}$ \\
\hline 2006 & An & $24 \mathrm{~h}$ & ACS & NR & $21 / 59$ & NR & $\begin{array}{l}\text { Non-fatal reinfarction, non-fatal heart } \\
\text { failure, recurrent angina attacks, drug } \\
\text { intensification or emergency revascu- } \\
\text { larization, and cardiac death }\end{array}$ & ELISA & NR & 30 days \\
\hline 2005 & Lee & $\begin{array}{l}\text { Admission, } \\
48 \mathrm{~h}\end{array}$ & ACS & $\begin{array}{l}67 / \\
70\end{array}$ & $24 / 34$ & $\begin{array}{l}\text { Antiplatelet, } \\
\text { Anticoagulation }\end{array}$ & $\begin{array}{l}\text { Death, } \mathrm{Ml} \text {, and refractory angina } \\
\text { requiring revascularisation }\end{array}$ & ELISA & $8 / 6$ & 30 days \\
\hline 2005 & Warlo & $24 \mathrm{~h}$ & $C A D$ & NR & $73 / 927$ & Antiplatelet & $\begin{array}{l}\text { Unstable angina pectoris, MI, non } \\
\text { haemorrhagic stroke and death }\end{array}$ & NR & NR & 2 years \\
\hline 2003 & Niessner & Admission & $C A D$ & $\begin{array}{l}56 / \\
52\end{array}$ & $103 / 38$ & NR & $\begin{array}{l}\text { All-cause mortality and } \mathrm{Ml} \text {, } \\
\text { revascularization procedures including } \\
\text { PTCA with/without coronary stenting } \\
\text { and ACBG. }\end{array}$ & ELISA & NR & $\begin{array}{l}13 \\
\text { years }\end{array}$ \\
\hline 2002 & Eikelboom & Admission & ACS & NR & 78/407 & $\begin{array}{l}\text { Anticoagulant, } \\
\text { Antiplatelet }\end{array}$ & $\begin{array}{l}\text { CV death, Ml, stroke or refractory } \\
\text { ischaemia }\end{array}$ & NR & NR & 30 days \\
\hline 2000 & Redondo & Admission & $C A D$ & $\begin{array}{l}59 / \\
57\end{array}$ & $37 / 157$ & NR & $\begin{array}{l}\text { Fatal MI, non-fatal MI, percutaneous } \\
\text { transluminal coronary angioplasty or } \\
\text { CABG. }\end{array}$ & ELISA & NR & 2 years \\
\hline 1999 & Moss & Admission & Ml & $\begin{array}{l}59 / \\
47\end{array}$ & $81 / 964$ & NR & $\begin{array}{l}\text { Death due to coronary heart disease } \\
\text { or recurrent nonfatal Ml }\end{array}$ & ELISA & NR & $\begin{array}{l}26 \\
\text { months }\end{array}$ \\
\hline 1998 & Montalescot & $\begin{array}{l}\text { Admission, } \\
48 \mathrm{~h}\end{array}$ & $C A D$ & $\begin{array}{l}70 / \\
70\end{array}$ & $48 / 20$ & Antiplatelet & $\begin{array}{l}\text { Death, Ml, recurrent angina, or } \\
\text { revascularization }\end{array}$ & ELISA & NR & 30 days \\
\hline
\end{tabular}

Abbreviations: $A C B G$ aorto coronary bypass graft, $A C S$ acute coronary syndromes, $A M I$ acute myocardial infarction, $C A B G$ coronary artery bypass grafting, $C / C T L$ case/control group, CV cardiovascular, ELISA enzyme-linked immunosorbent assay, HF heart failure, NR unreported, LV left ventricular, MI myocardial infarction, non-STEMI non-ST-elevated myocardial infarction, PCI percutaneous coronary intervention, PTCA percutaneous transluminal coronary angioplasty, STMI ST-elevated myocardial infarction

anticoagulation contribute to heterogeneity in vWF plasma levels examined at $24 \mathrm{~h}$ after admission (high range of follow up sample size: $P=0.033$; the utilization of antiplatelet or anticoagulation: $P=0.007$ ).

\section{Sensitivity analyses}

Each study was excluded sequentially to evaluate the influence of an individual study on the results. No study fundamentally changed the combined effects at any time points. Furthermore, the study by Warlo [10] was found to be the source of heterogeneity. When the study was eliminated from analysis, heterogeneity become minimal (examined on $24 \mathrm{~h}$ : SMD $=0.67,95 \% \mathrm{CI}=0.47-0.86, P<$ $\left.0.00001, \mathrm{I}^{2}=0 \%\right)$.

\section{Publication bias}

Funnel plot was performed to evaluate the publication bias of literatures. As shown in Fig. 3. 


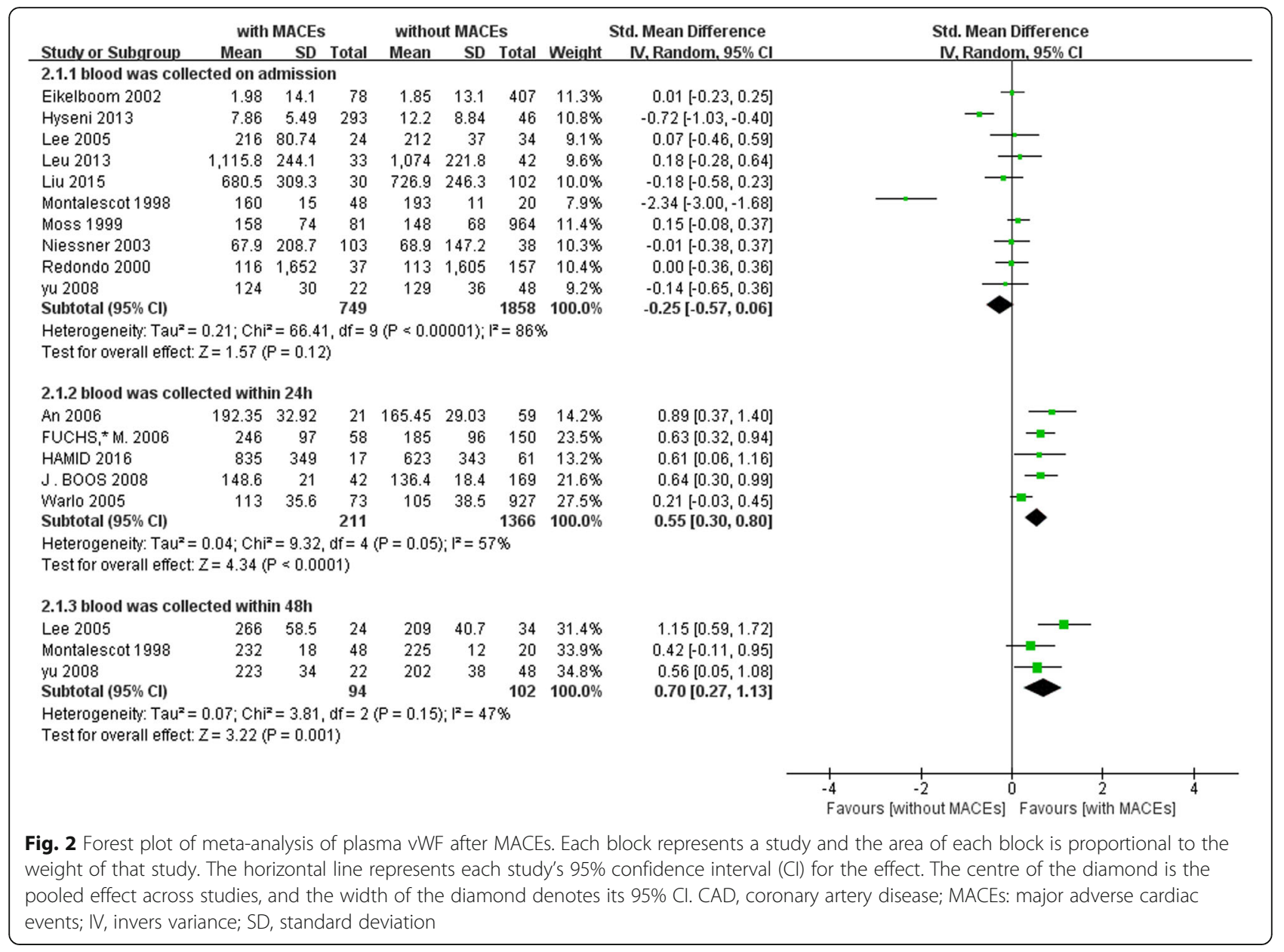

Table 2 Quality assessment of the included studies based on the Newcastle-Ottawa Scale

\begin{tabular}{|c|c|c|c|c|c|}
\hline Author & Study design & Selection & Comparability & Outcome & Total scores \\
\hline HAMID & Cohort study & 3 & 2 & 2 & 7 \\
\hline Liu & Cohort study & 3 & 2 & 3 & 8 \\
\hline Leu & Cohort study & 3 & 2 & 3 & 8 \\
\hline Hyseni & Cohort study & 3 & 1 & 2 & 6 \\
\hline yu & Cohort study & 3 & 2 & 2 & 7 \\
\hline BOOS & Cohort study & 3 & 2 & 3 & 8 \\
\hline Fuchs & Cohort study & 2 & 2 & 2 & 6 \\
\hline$A n$ & Cohort study & 2 & 2 & 2 & 6 \\
\hline Lee & Cohort study & 3 & 2 & 3 & 8 \\
\hline Warlo & Cohort study & 2 & 2 & 3 & 7 \\
\hline Niessner & Cohort study & 3 & 2 & 2 & 7 \\
\hline Eikelboom & Cohort study & 3 & 2 & 2 & 7 \\
\hline Redondo & Cohort study & 3 & 2 & 2 & 7 \\
\hline Montalescot & Cohort study & 2 & 2 & 3 & 7 \\
\hline Moss & Cohort study & 2 & 2 & 3 & 7 \\
\hline
\end{tabular}


Table 3 Subgroup analyses on MACEs

\begin{tabular}{|c|c|c|c|c|c|c|c|c|c|}
\hline \multirow[t]{2}{*}{ Subgroup } & & \multirow{2}{*}{$\begin{array}{l}\text { No. of } \\
\text { studies }\end{array}$} & \multicolumn{2}{|c|}{ No. of subjects } & \multicolumn{3}{|c|}{ Meta-analysis } & \multicolumn{2}{|c|}{ Heterogeneity } \\
\hline & & & $\overline{\text { MACES }}$ & $\overline{\text { Non MACES }}$ & $\overline{S M D}$ & $95 \% \mathrm{Cl}$ & $P$ & $\overline{1^{2}(\%)}$ & $P$ \\
\hline \multicolumn{10}{|l|}{ Follow-up duration } \\
\hline \multirow[t]{2}{*}{ On admission } & $<1$ year & 4 & 172 & 509 & -0.57 & $-1.44-0.3$ & 0.2 & 93 & $<0.00001$ \\
\hline & $\geq 1$ year & 6 & 577 & 1349 & -0.10 & $-0.39-0.19$ & 0.5 & 76 & 0.0007 \\
\hline \multirow[t]{2}{*}{$24 \mathrm{~h}$} & $<1$ year & 2 & 38 & 120 & 0.76 & $0.38-1.13$ & $<0.0001$ & 0 & 0.47 \\
\hline & $\geq 1$ year & 3 & 173 & 1246 & 0.48 & $0.17-0.78$ & 0.002 & 69 & 0.04 \\
\hline \multicolumn{10}{|l|}{ Type of CAD } \\
\hline \multirow[t]{2}{*}{ On admission } & CAD & 4 & 221 & 257 & -0.20 & $-0.42-0.01$ & 0.06 & 93 & $<0.00001$ \\
\hline & ACS、MI & 6 & 528 & 1601 & -0.09 & $-0.22-0.04$ & 0.16 & 76 & 0.04 \\
\hline \multirow[t]{2}{*}{$24 \mathrm{~h}$} & $C A D$ & 1 & 73 & 927 & 0.21 & $-0.03-0.45$ & 0.09 & & \\
\hline & ACS、MI & 4 & 138 & 439 & 0.67 & $0.47-0.86$ & $<0.00001$ & 0 & 0.86 \\
\hline \multicolumn{10}{|l|}{$\mathrm{PCl}$} \\
\hline \multirow[t]{2}{*}{ On admission } & Yes & 2 & 323 & 148 & -0.46 & $-0.99-0.07$ & 0.09 & 76 & 0.04 \\
\hline & No & 8 & 426 & 1710 & -0.20 & $-0.55-0.15$ & 0.27 & 86 & 0.00001 \\
\hline \multirow[t]{2}{*}{$24 \mathrm{~h}$} & Yes & 3 & 117 & 380 & 0.63 & $0.42-0.84$ & $<0.00001$ & 0 & 1 \\
\hline & No & 2 & 94 & 986 & 0.33 & $0.11-0.54$ & 0.003 & 82 & 0.02 \\
\hline
\end{tabular}

Abbreviations No number, $M I$ myocardial infarction, $S M D$ standardized mean difference, $N R$ unreported, $C l$ confidence interval, $A C S$ acute coronary syndromes, $C A D$ coronary artery disease, MACEs major adverse cardiac events

\section{Discussion}

This meta-analysis summarizes evidence for association between high-circulation vWF levels and clinically adverse outcomes in patients with CAD. The data on plasma vWF at three time points was included. Results indicated that the plasma vWF was significantly increased in the adverse event group on $24 \mathrm{~h}$ and $48 \mathrm{~h}$ after primary CAD. However, the level of $\mathrm{vWF}$ on

Table 4 Source of heterogeneity by meta-regression analysis

\begin{tabular}{llll}
\hline Factors & Coefficient & Standard error & $P$ \\
\hline Follow-up duration & & & \\
On admission & 0.4594606 & 0.4769995 & 0.364 \\
24h & 0.7399235 & 0.1979834 & 0.033 \\
Type of CAD & & & \\
On admission & -0.3537444 & 0.4880535 & 0.489 \\
24h & 0.4633034 & 0.1574912 & 0.06 \\
PCl & & & \\
On admission & -0.2209772 & 0.6057707 & 0.725 \\
24h & 0.3064662 & 0.2227691 & 0.263 \\
Regular anticoagulant drugs & & \\
On admission & 0.3608304 & 0.5222992 & 0.509 \\
24h & 0.6721909 & 0.1000211 & 0.007 \\
Antiplatelet & & & \\
On admission & -0.3252659 & 0.4913701 & 0.527 \\
24h & 0.6721909 & 0.1000211 & 0.007 \\
\hline
\end{tabular}

admission showed no significant difference between the two groups. Subgroup analyses revealed that the association of increased vWF level with short-term MACEs is stronger. In addition, increased vWF level displays a positive association on MACEs in ACS and MI other than stable CAD. Together, our results suggested that plasma level of vWF is an indicator for the risk of MACEs among patients with CAD.

vWF is mainly synthesized in endothelial cells $[25,26]$. Upon endothelial cell injury, vWF is released into the blood circulation. In blood plasma, vWF binds to platelet receptors GPIb-IX-V, GPIIb/IIIa and GPIb to promote thrombosis $[27,28]$. The combination of vWF and collagen causes a conformational change in the site of $\mathrm{vWF}$ binding to factor VIII, which promotes fibrin agglutination $[29,30]$. VWF also mediates platelet adhesion on activated endothelial cells, enhancing thrombus formation even in the absence of endothelial denudation [31]. Several studies have reported that high plasma vWF levels are associated with endothelial dysfunction and inflammation [32, 33], which contribute to the cardiovascular risks. In addition, vWF involves in the pathogenesis of atherosclerosis [34].

MACEs, such as nonfatal myocardial infarction, nonfatal stroke, or target vessel revascularization, are more likely to occur in patients with severe CAD [3]. The increased risk of vWF for MACEs in CAD may be caused by prothrombotic or hypercoagulable conditions, which promote the formation of occlusive thrombus [35]. Both acute myocardial infarction (AMI) and stroke are precipitated by an occlusive thrombus on a preexisting atherosclerotic plaque 


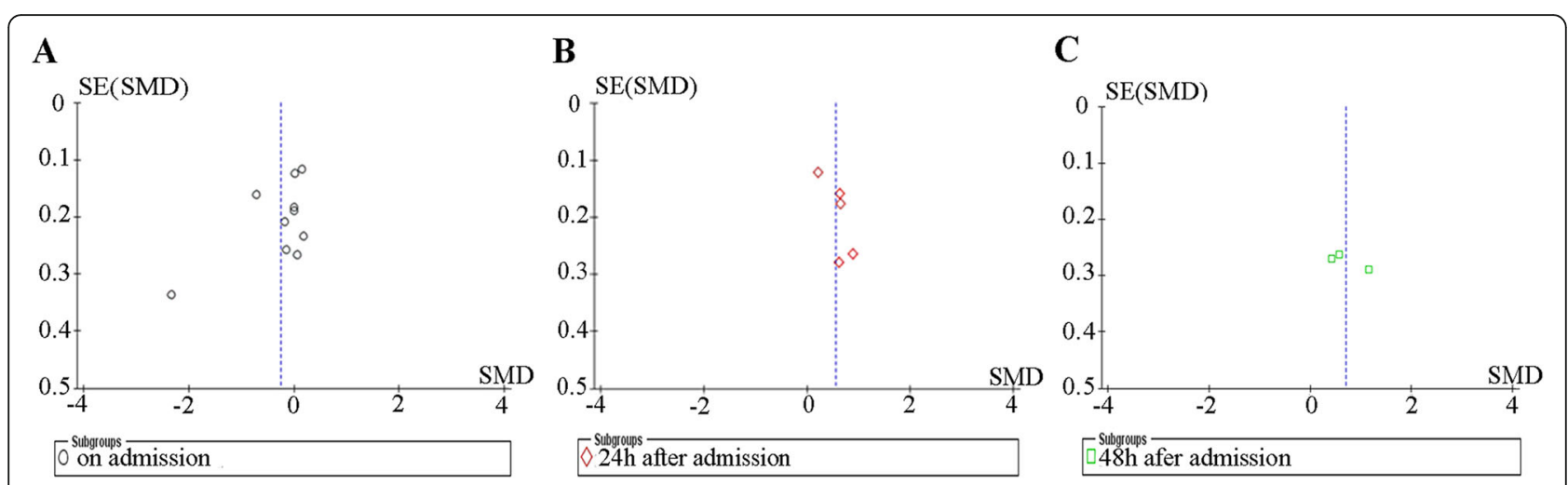

Fig. 3 Funnel plot of publication bias. No publication bias was presented in any groups. a Funnel plot of studies on admission of vWF levels. $\mathbf{b}$ Funnel plot of studies at $24 \mathrm{~h}$ after admission of vWF levels. c Funnel plot of studies at $48 \mathrm{~h}$ after admission of vWF levels

[36]. VWF promotes thrombus formation by mediating platelet adhesion and aggregation [36]. The inflammatory response involved in the progression of atherosclerotic plaques may also promote an increased secretion of vWF [37]. Therefore, vWF may be considered as a potential clinical biomarker. Previous studies reported that PCI leads to a significant increase of vWF levels compared with the pre-procedural levels [38]. PCI itself causes endothelial cell damage due to mechanical injury by catheter manipulations [39]. In addition, hemodynamic effects of transient myocardial injury during PCI contributes to the increased vWF levels [40].

The prognostic role of vWF in patients with CAD is even more convinced than other acute phase-reactive proteins such as his-CRP and fibrinogen [41]. Studies have shown that elevated early vWF levels in patients with CAD are an independent predictor of adverse events over the next 2 weeks to 1 month, whereas other acute phase response proteins are not [42]. Compared with reactive proteins, vWF is released locally during vascular injury without new synthesis of proteins. Recent case-control studies also demonstrated that the higher plasma vWF or lower ADAMTS13 levels were closely associated with the risk of MI [33, 43-45], ischaemic stroke [46]. However, the present study is the first meta analysis that highlights the long-term prognostic value of plasma vWF levels in patients with CAD.

Our study has several advantages. First, vWF is a promised indicator of the clinical outcome in patients with coronary artery disease. The dramatic increase of plasma vWF implies its potential roles in the diagnosis of CAD. Second, all the studies included in this metaanalysis were medium-to-high quality as assessed by Newcastle-Ottawa Quality Assessment Scale. Third, publication bias assessment confirmed the robustness and reliability of our results. Moreover, circulating vWF level was collected on admission, $24 \mathrm{~h}$ and $48 \mathrm{~h}$ after primary CAD respectively, which provides a variation of
vWF with the progression of disease. Our study has several limitations. First, the number of studies of duration on $24 \mathrm{~h}$ or $48 \mathrm{~h}$ available for meta analyzes was relatively small. Second, the articles included many types of coronary artery disease including acute coronary syndrome, myocardial infarction, angina, which may contributes to clinical heterogeneity. Third, detailed information regarding symptom duration was not available in several studies.

\section{Conclusion}

Plasma vWF levels of CAD patients examined at $24 \mathrm{~h}$ and $48 \mathrm{~h}$ after admission might be an independent prognostic factor for MACE. However, many studies had incomplete information, and more studies with more detailed data and sufficient sample size are necessary to confirm our findings.

\section{Abbreviations}

95\%Cl: 95\% confidence intervals; ACS: Acute coronary syndromes; AMl: Acute myocardial infarction; CAD: Coronary artery disease; CK-MB: Creatine kinase

MB ECG: electro cardio graph; IQR: Inter quartile range; MACEs: Major adverse cardiac events; non-STEMI: Non-ST-elevated myocardial infarction;

NOS: Newcastle-Ottawa quality assessment scale; PCl: Percutaneous coronary intervention; SD: Standard deviation; SE: Standard error; SMD: Standard mean difference; STMI: ST-elevated myocardial infarction; vWF: von Willebrand factor

\section{Acknowledgements}

None.

\section{Authors' contributions}

$J L$ conceived the study. MF wrote the draft of the manuscript, performed the database search and researched the data. MF, XW and XP performed dataextraction of the papers. MF and SF performed quality ratings of the papers. MF and JL performed the data analyses. JZ, YZ, LL and YH interpreted the data, and critically reviewed/edited the manuscript. All authors have read and given final approval of the version to be published.

\section{Funding}

This research was supported by the grants The National Natural Science Foundation of China (81370269), and Shandong Taishan Scholarship (Ju Liu). The funders had no role in study design, data collection and analysis, decision to publish, or preparation of the manuscript. 


\section{Availability of data and materials}

All data generated or analyzed in this study are included in this manuscript.

\section{Ethics approval and consent to participate}

Not applicable.

\section{Consent for publication}

Not applicable.

\section{Competing interests}

The authors declare that they have no competing interests.

\section{Author details}

'Laboratory of Microvascular Medicine, Medical Research Center, Shandong Provincial Qianfoshan Hospital, The First Affiliated Hospital of Shandong First Medical University, 16766 Jingshi Road, Jinan 250014, Shandong, China.

${ }^{2}$ Graduate School, Shandong First Medical University \& Shandong Academy of Medical Sciences, Jinan, China. ${ }^{3}$ School of Medicine, Shandong University, Jinan, China. ${ }^{4}$ Department of Endocrinology, Shandong Provincial Qianfoshan Hospital, The First Affiliated Hospital of Shandong First Medical University, Jinan, China. ${ }^{5}$ Department of Cardiology, Shandong Provincial Qianfoshan Hospital, The First Affiliated Hospital of Shandong First Medical University, Jinan, China.

\section{Received: 16 March 2019 Accepted: 3 February 2020}

Published online: 10 February 2020

\section{References}

1. Singh RS, Saini BS, Sunkaria RK. Detection of coronary artery disease by reduced features and extreme learning machine. Clujul Med. 2018;91(2): 166-75.

2. Poddar MG, Kumar V, Sharma YP. Automated diagnosis of coronary artery diseased patients by heart rate variability analysis using linear and nonlinear methods. J Med Eng Technol. 2015;39(6):331-41.

3. Lee KW, Blann AD, Lip GY. Plasma markers of endothelial damage/ dysfunction, inflammation and thrombogenesis in relation to TIMI risk stratification in acute coronary syndromes. Thromb Haemost. 2005;94(5): 1077-83.

4. Liu KL, Lin SM, Chang CH, Chen YC, Chu PH. Plasma angiopoietin-1 level, left ventricular ejection fraction, and multivessel disease predict development of 1-year major adverse cardiovascular events in patients with acute ST elevation myocardial infarction - a pilot study. Int J Cardiol. 2015; 182:155-60.

5. Bansilal S, Castellano JM, Fuster V. Global burden of CVD: focus on secondary prevention of cardiovascular disease. Int J Cardiol. 2015;201:S1-7.

6. Whincup P. von Willebrand factor and coronary heart disease. Prospective study and meta-analysis. Eur Heart J. 2002;23(22):1764-70.

7. Koprivica Z, Djordjevic D, Vuletic M, Zivkovic V, Barudzic N, Andjelkovic N, Djuric D, Iric-Cupic V, Krkeljic J, Jakovljevic V. Von Willebrand factor and oxidative stress parameters in acute coronary syndromes. Oxidative Med Cell Longev. 2011;2011:918312.

8. Wang X, Dong F, Wang F, Yan S, Chen X, Tozawa H, Ushijima T, Kapron CM, Wada Y, Liu J. Low dose cadmium upregulates the expression of von Willebrand factor in endothelial cells. Toxicol Lett. 2018;290:46-54

9. Miura M, Kaikita K, Matsukawa M, Soejima K, Fuchigami S, Miyazaki Y, Ono T, Uemura T, Tsujita K, Hokimoto S, et al. Prognostic value of plasma von Willebrand factor-cleaving protease (ADAMTS13) antigen levels in patients with coronary artery disease. Thromb Haemost. 2010;103(3):623-9.

10. Warlo EMK, Pettersen AR, Arnesen H, Seljeflot I. vWF/ADAMTS13 is associated with on-aspirin residual platelet reactivity and clinical outcome in patients with stable coronary artery disease. Thromb J. 2017;15:28.

11. Wang X, Zhao J, Zhang Y, Xue X, Yin J, Liao L, Xu C, Hou Y, Yan S, Liu J. Kinetics of plasma von Willebrand factor in acute myocardial infarction patients: a meta-analysis. Oncotarget. 2017;8(52):90371-9.

12. Pinsky DJ, Naka Y, Liao H, Oz MC, Wagner DD, Mayadas TN, Johnson RC, Hynes RO, Heath M, Lawson CA, et al. Hypoxia-induced exocytosis of endothelial cell Weibel-Palade bodies. A mechanism for rapid neutrophil recruitment after cardiac preservation. J Clin Invest. 1996;97(2):493-500.

13. Fuchs I, Frossard M, Spiel A, Riedmuller E, Laggner AN, Jilma B. Platelet function in patients with acute coronary syndrome (ACS) predicts recurrent ACS. J Thromb Haemost. 2006;4(12):2547-52.
14. Boos CJ, Balakrishnan B, Blann AD, Lip GY. The relationship of circulating endothelial cells to plasma indices of endothelial damage/dysfunction and apoptosis in acute coronary syndromes: implications for prognosis. J Thromb Haemost. 2008;6(11):1841-50.

15. Leu HB, Lin CP, Lin WT, Wu TC, Chen JW. Risk stratification and prognostic implication of plasma biomarkers in nondiabetic patients with stable coronary artery disease: the role of high-sensitivity C-reactive protein. Chest. 2004;126(4):1032-9.

16. Redondo M, Carroll VA, Mauron T, Biasiutti FD, Binder BR, Lammle B, Wuillemin WA. Hemostatic and fibrinolytic parameters in survivors of myocardial infarction: a low plasma level of plasmin-alpha2-antiplasmin complex is an independent predictor of coronary re-events. Blood Coagul Fibrinolysis. 2001;12(1):17-24.

17. Montalescot G, Philippe F, Ankri A, Vicaut E, Bearez E, Poulard JE, Carrie D, Flammang D, Dutoit A, Carayon A, et al. Early increase of von Willebrand factor predicts adverse outcome in unstable coronary artery disease: beneficial effects of enoxaparin. French investigators of the ESSENCE trial. Circulation. 1998;98(4):294-9.

18. Eikelboom J. Clopidogrel does not suppress blood markers of coagulation activation in aspirin-treated patients with non-ST-elevation acute coronary syndromes. Eur Heart J. 2002;23(22):1771-9.

19. Niessner A, Graf S, Nikfardjam M, Speidl WS, Huber-Beckmann R, Zorn G, Wojta J, Huber K. Circulating t-PA antigen predicts major adverse coronary events in patients with stable coronary artery disease--a 13-year follow-up. Thromb Haemost. 2003;90(2):344-50.

20. Moss AJ, Goldstein RE, Marder VJ, Sparks CE, Oakes D, Greenberg H, Weiss HJ, Zareba W, Brown MW, Liang CS, et al. Thrombogenic factors and recurrent coronary events. Circulation. 1999;99(19):2517-22.

21. Abdel Hamid M, Bakhoum SW, Sharaf Y, Sabry D, El-Gengehe AT, Abdel-Latif A. Circulating endothelial cells and endothelial function predict major adverse cardiac events and early adverse left ventricular remodeling in patients with ST-segment elevation myocardial infarction. J Interv Cardiol. 2016;29(1):89-98.

22. Yu D, Jia SQ. Increase of von Willebrand factor predicting adverse outcome patients of acute coronary syndromes with non-ST-segmentelevation. J Hangzhou Teachers College (Medical Edition); 2008;28(3):148-55.

23. Hyseni A, Roest M, Braun SL, Barendrecht AD, de Groot PG, Ndrepepa G, Kastrati A. Chronic dysfunction of the endothelium is associated with mortality in acute coronary syndrome patients. Thromb Res. 2013;131(3): 198-203.

24. An GX, Chai YR,Cai H. Correlation between plasma vWF and PAI- 1 levels and coronary artery stenosis in ACS patients. Integr Med Oncardio Cerebrovasc Dis. 2010;8(11):1305-06.

25. Kanaji S, Fahs SA, Shi Q, Haberichter SL, Montgomery RR. Contribution of platelet vs. endothelial WWF to platelet adhesion and hemostasis. J Thromb Haemost. 2012;10(8):1646-52.

26. Xu Y, Pan S, Liu J, Dong F, Cheng Z, Zhang J, Qi R, Zang Q, Zhang C, Wang $X$, et al. GATA3-induced VWF upregulation in the lung adenocarcinoma vasculature. Oncotarget. 2017:8(66):110517-29.

27. Castaman G, Hillarp A, Goodeve A. Laboratory aspects of von Willebrand disease: test repertoire and options for activity assays and genetic analysis. Haemophilia. 2014;20(Suppl 4):65-70.

28. Hobbs WE, Moore EE, Penkala RA, Bolgiano DD, Lopez JA. Cocaine and specific cocaine metabolites induce von Willebrand factor release from endothelial cells in a tissue-specific manner. Arterioscler Thromb Vasc Biol. 2013;33(6):1230-7

29. Dayananda KM, Singh I, Mondal N, Neelamegham S. von Willebrand factor self-association on platelet Gplbalpha under hydrodynamic shear: effect on shear-induced platelet activation. Blood. 2010;116(19):3990-8.

30. Li Y, Li L, Dong F, Guo L, Hou Y, Hu H, Yan S, Zhou X, Liao L, Allen TD, et al. Plasma von Willebrand factor level is transiently elevated in a rat model of acute myocardial infarction. Exp Ther Med. 2015;10(5):1743-9.

31. Andre P, Denis CV, Ware J, Saffaripour S, Hynes RO, Ruggeri ZM, Wagner DD. Platelets adhere to and translocate on von Willebrand factor presented by endothelium in stimulated veins. Blood. 2000;96(10):3322-8.

32. Matsukawa M, Kaikita K, Soejima K, Fuchigami S, Nakamura Y, Honda T, Tsujita K, Nagayoshi Y, Kojima S, Shimomura H, et al. Serial changes in von Willebrand factor-cleaving protease (ADAMTS13) and prognosis after acute myocardial infarction. Am J Cardiol. 2007;100(5):758-63.

33. Danesh J, Wheeler JG, Hirschfield GM, Eda S, Eiriksdottir G, Rumley A, Lowe GD, Pepys MB, Gudnason V. C-reactive protein and other circulating markers 
of inflammation in the prediction of coronary heart disease. N Engl J Med. 2004;350(14):1387-97.

34. Gragnano F, Sperlongano S, Golia E, Natale F, Bianchi R, Crisci M, Fimiani F, Pariggiano I, Diana V, Carbone A, et al. The role of von Willebrand factor in vascular inflammation: from pathogenesis to targeted therapy. Mediat Inflamm. 2017;2017:5620314.

35. Roquer J, Segura T, Serena J, Castillo J. Endothelial dysfunction, vascular disease and stroke: the ARTICO study. Cerebrovasc Dis. 2009;27(Suppl 1):25-37.

36. Vischer UM. von Willebrand factor, endothelial dysfunction, and cardiovascular disease. J Thromb Haemost. 2006;4(6):1186-93.

37. Horii M, Uemura S, Uemura M, Matsumoto M, Ishizashi H, Imagawa K, Iwama H, Takeda Y, Kawata H, Nakajima T, et al. Acute myocardial infarction as a systemic prothrombotic condition evidenced by increased von Willebrand factor protein over ADAMTS13 activity in coronary and systemic circulation. Heart Vessel. 2008:23(5):301-7.

38. Boos CJ, Balakrishnan B, Jessani S, Blann AD, Lip GY. Effects of percutaneous coronary intervention on peripheral venous blood circulating endothelial cells and plasma indices of endothelial damage/dysfunction. Chest. 2007; 132(6):1920-6.

39. Boos CJ, Lip GY, Blann AD. Circulating endothelial cells in cardiovascular disease. J Am Coll Cardiol. 2006;48(8):1538-47.

40. Vargova K, Toth-Zsamboki E, Beres BJ, Bencze J, Kerecsen G, Gulacsi-Bardos $P$, Kiss RG, Preda I. Circulating endothelial cell count, plasma vWF and soluble ICAM-1 levels following primary or elective percutaneous coronary intervention. Atherosclerosis. 2008;198(2):366-72.

41. Park Y, Kim KH, Kang MG, Ahn JH, Jang JY, Park HW, Koh JS, Park JR, Hwang SJ, Jeong YH, et al. Antiplatelet therapy combinations and Thrombogenicity in patients with non-Valvular atrial fibrillation. Korean Circ J. 2017;47(3):366-76.

42. Montalescot G, Collet JP, Choussat R, Ankri A, Thomas D. A rise of troponin and/or von Willebrand factor over the first $48 \mathrm{~h}$ is associated with a poorer 1-year outcome in unstable angina patients. Int J Cardiol. 2000;72(3):293-4.

43. Chion CK, Doggen CJ, Crawley JT, Lane DA, Rosendaal FR. ADAMTS13 and von Willebrand factor and the risk of myocardial infarction in men. Blood. 2007;109(5):1998-2000

44. Crawley JT, Lane DA, Woodward M, Rumley A, Lowe GD. Evidence that high von Willebrand factor and low ADAMTS-13 levels independently increase the risk of a non-fatal heart attack. J Thromb Haemost. 2008;6(4):583-8.

45. Jia $\mathrm{XQ}$, Dong $\mathrm{CM}$, Qin J, Zhang L. Changes in coagulation and fibrinolysis in the patients with coronary heart disease in acute period and effect of drug intervention. Zhongguo Wei Zhong Bing Ji Jiu Yi Xue. 2012;24(4):225-8.

46. Bongers TN, de Maat MP, van Goor ML, Bhagwanbali V, van Vliet HH, Gomez Garcia EB, Dippel DW, Leebeek FW. High von Willebrand factor levels increase the risk of first ischemic stroke: influence of ADAMTS13, inflammation, and genetic variability. Stroke. 2006;37(11):2672-7.

\section{Publisher's Note}

Springer Nature remains neutral with regard to jurisdictional claims in published maps and institutional affiliations.

Ready to submit your research? Choose BMC and benefit from:

- fast, convenient online submission

- thorough peer review by experienced researchers in your field

- rapid publication on acceptance

- support for research data, including large and complex data types

- gold Open Access which fosters wider collaboration and increased citations

- maximum visibility for your research: over $100 \mathrm{M}$ website views per year

At BMC, research is always in progress.

Learn more biomedcentral.com/submissions 